\title{
大学における初年次教育の現状と課題
}

Current status and issues of first-year experience in higher education

川合 宏之 ${ }^{1}$

1流通科学大学商学部

Hiroyuki Kawai ${ }^{1}$

${ }^{1}$ Faculty of Commerce, University of Marketing and Distribution Sciences

3-1 Gakuen-Nishimachi, Nishi-ku, Kobe, Hyogo, Japan 651-2188

キーワード : 初年次教育，高大接続，カリキュラム，プログラム

Key words : Japanese association of first-year experience,

Articulation between high school and universities, Curriculum, Program

\section{一 抄録}

本論では, 高大接続改革と初年次教育の現状について論じた上で, 今後の課題について考察する. 高大接続改革においては，高等学校や大学における大学の評価基準を変更する方向性が示されてい る. 一方, 初年次教育では, 大学側が求める能力と入学時の学生の能力のギャップを埋めようとす る試みがなされている. 両方には課題があり, 前者は大学において必要となる基礎学力を得る動機 づけを学生から奪う恐れがあり，後者には，大学側の膨大な人的コストが問題となる.

\section{1. はじめに}

大学の全志願者数に対する入学者数の割合が 100\%を超えたことにより，現在の日本は「大学全 入時代」と呼ばれる時代にある。また入学者の選 抜方法も，学力だけによる入試から，推薦入試や $\mathrm{AO}$ 入試といった人物を総合的に評価する方法へ と多様化している.

しかし，こうした大学進学率の高まりや入試形 態の多様化は，学生の大学入学時点における基礎 学力不足という問題を招いている. その一方で, 「与えられた問いに答える」学習から，「自ら問い
を作りだす」学習へと転換する大学において, 学 生には高い基礎学力が求められることとなる. 現 在，大学ではこのギャップをいかに解決するかが 課題となっている，そして，その対策として近年 注目されているのが，高大接続改革と初年次教育 である。本論では，高大接続改革と初年次教育の 現状について解説した上で，今後の課題について 考察する.

\section{2. 高大接続改革}

2.1. 推䳸入試 $\cdot \mathrm{AO}$ 入試の増加

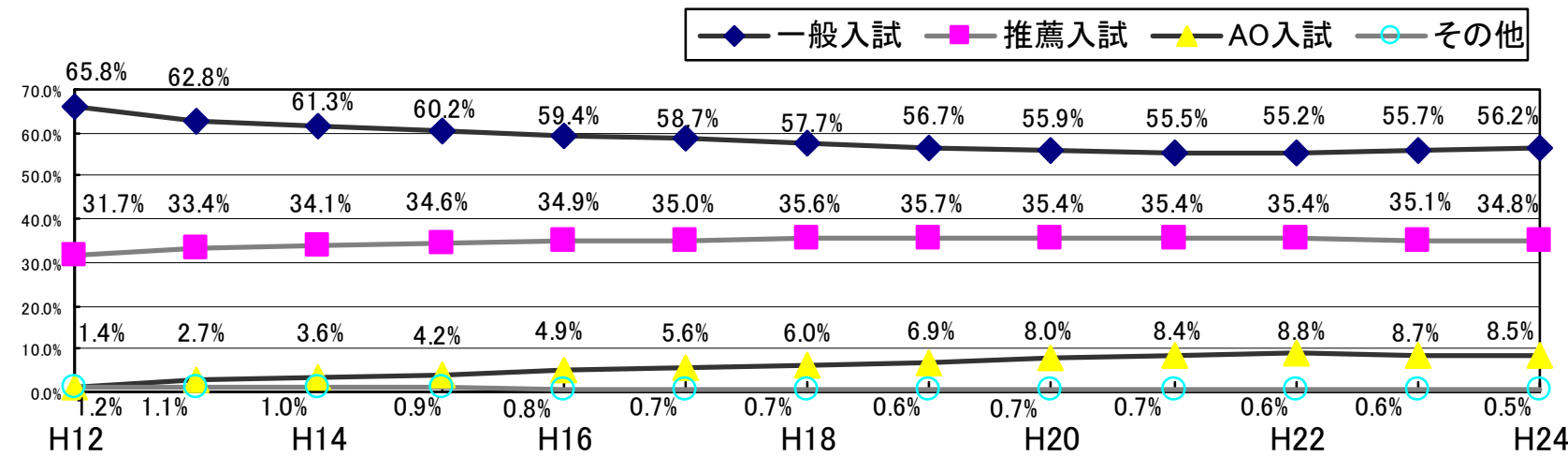

図 1. 入学者割合の推移 
図 1 は中央教育審議会（以下，中教審）高大接 続特別部会資料「AO 入試等の実施状況について」 [1]に記載されている「2. 選抜方法別入学者の推移(2) 入学者割合の推移」である(p.4).ここからわかる ように，2000（平成 12）年度において, 各選抜方 法による入学者の割合は，一般入試が $65.8 \%$, 推

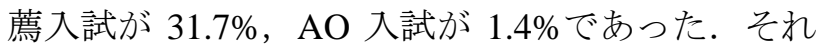
が，2012（平成 24）年度においては，一般入試で $56.2 \%$, 推薦入試で $34.8 \%, \mathrm{AO}$ 入試で $8.5 \%$ とな
っている．その結果，私立大学では約半数が推薦 入試・AO 入試によって入学しているという状況 (p.2)になった。

推薦入試やAO入試では，学校の調査書，面接, 小論文などによって受験者を評価する。これは， 学力以外の能力・適性を測ろうという試みである。 しかし，こうした選抜方法では，高等学校の履修 科目の学習到達度を測る一般入試と比べて学力が あまり重視されていない状況にあると言える。

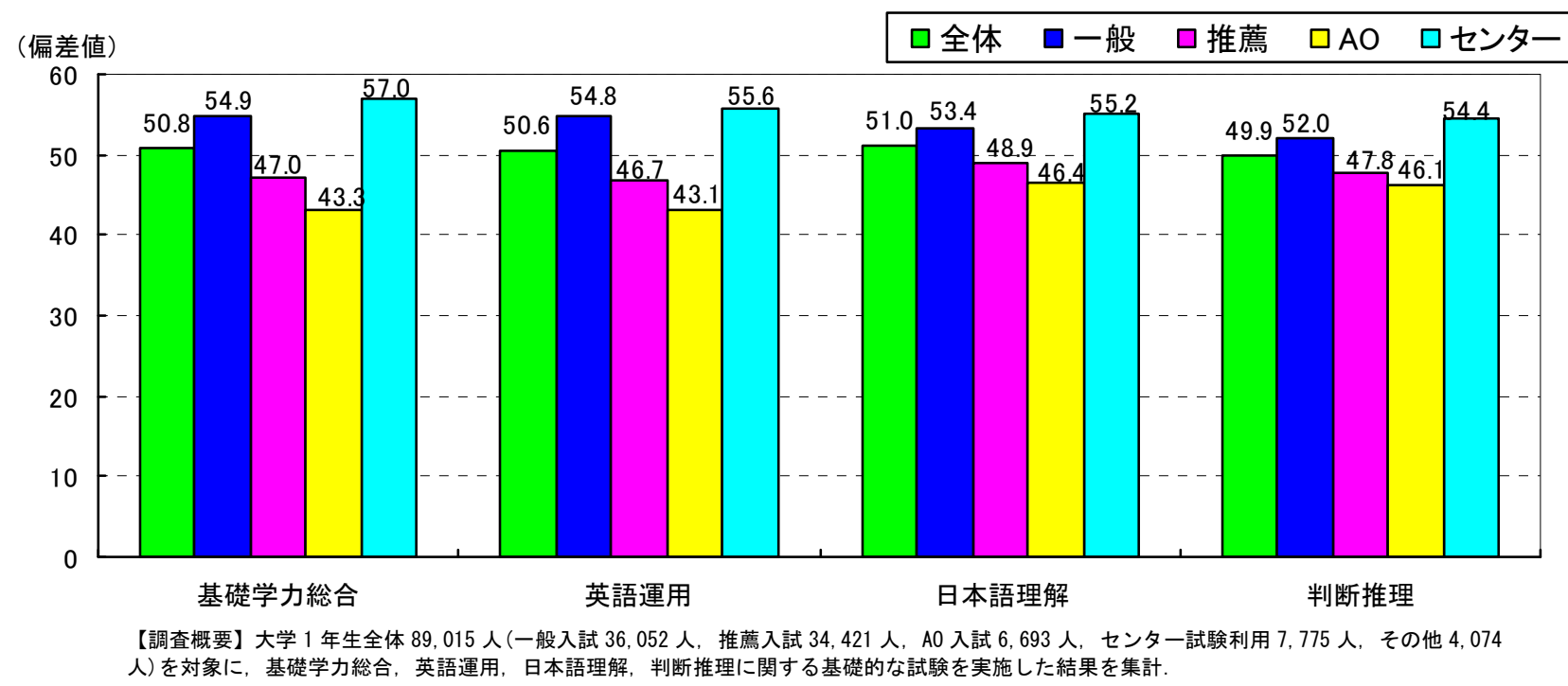

図 2. 大学生の入試方法別基礎学力

四2からわかるように, ベネッセコーポレーショ ン大学事業部が2011年に行った「大学生基礎力調 查 I」によると, 「基礎学力」「英語運用」「日本語 理解」「判断推理」のいずれの項目においても, 一 般入試入学者の偏差值が最も高く, 次いで推薦入

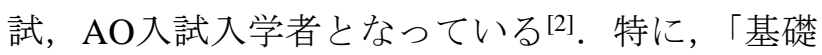
学力総合」における差が最も激しく, 一般入試入 学者と $\mathrm{AO}$ 入試入学者の偏差值の差は 10 ポイント 以上となっている。また, 高偏差值層の割合で見 ても, 偏差值55以上の学生の割合が一般入試では 43.7\%であるのに対し，推薦入試では22.6\%，AO 入試では $12.2 \%$ とっている。また, 最上位層であ る偏差值65以上の学生の割合についても，一般入 試が $12.4 \%$ である方，推薦入試では3.3\%，AO入 試では2.0\%となっている.このように，全体的に 見た時, 推薦入試・AO入試による入学者は一般入 試による入学者に比べて学力が低い者の割合が高 いと言える.

ただし, 一方では, AO 入試によって, 大学の教
育内容を深く理解し， かつ一般入試による入学者 と同等の学業成績を修める生徒を集めることに成 功していると報告する大学も存在している.

九州大学は AO 入試による入学者について,「受 験生は，アドミッション・ポリシーをよく理解す ることが必要となり, 結果として, 同大学の建学 の精神や各学部の教育内容を理解してから進学の 決意を固めることになる，そのため，目的意識が 高く, 学部への適合率の高い学生が入学してくる ことにつながっている。また， $\mathrm{AO}$ 選抜入学者は学 業成績においても, 学部・科目によって 異なるが, 総じて一般選抜入学生とほぼ同等程度である.」[3] と評価している.

こうした現状を背景として，中教審は「生きる 力」と「確かな学力」を育むために, 新しい時代 にふさわしい高大接続の実現を目指すことを方針 として定めている．次節では，2014年に中教審が 述べた高大接続改革の内容について説明する. 
2.2. 中央教育審議会答申

2014 年 12 月 22 日, 中教審は「新しい時代にふ さわしい高大接続の実現に向けた高等学校教育, 大学教育, 大学入学者選抜の一体的改革について 〜すべての若者が夢や目標を芽吹かせ，未来に花 開かせるために〜」において，今後の高大接続改 革の展望について述べている[4].

中教審は，今後の教育改革が目指す心゙き方向性 について，義務教育までの成果を確実につないだ 上で，「生きる力」「確かな学力」を確実に育み, 一人ひとりに育まれた力をさらに発展・向上させ ることが肝要であるとしている.ここにおける「確 かな学力」とは, かつての「ゆとり」か「詰め込 み」かといった二項対立を乗り越えた，「基礎的な 知識及び技能」「これらを活用して課題を解決す るために必要な思考力・判断力・表現力等の能力」 「主体的に学習に取り組む態度」という，「学力の 3 要素」によって構成されるものである(p.2-3).

こうした「確かな学力」を育むべき高等学校, 大学において, 中教審は現状の課題を 2 点指摘し ている(p.4-5). 以下にその要約を述べる.

1 点目は，高等学校における授業が知識伝達型 の授業に留まり，学力の 3 要素を踏まえた指導が 浸透していないという点である。この問題は大学 の一般入試との関係が深い。一般入試では，一斉 かつ画一的な条件で実施される試験で，あらかじ め設定された正答に関する知識の再生を 1 点刻み に問うものである。そのため, 高等学校での指導 もこうした一般入試の傾向に沿う形で行われるこ ととなる。

2 点目は 1 点目と関連するが，大学入学者選抜 の方法がこれからの大学教育で学ぶために必要な 力を評価するものとなっていない点である. 現在 の大学入試では，知識の記憶力などの測定しやす い一部の能力を重視する傾向にある。一斉受験と いう画一化された条件において，「公平性」を過度 に重視するあまり，決められた答えの点数を問う ことにより客観性を確保するという現在の選抜の 方法が維持されている.

中教審は，現在の高校教育が知識伝達型の授業 に留まり，また大学入試においても知識を問う問 題が中心になっていることを指摘している. 現在 行われている通常のテストでは，知識を確認する 問題が多い。そのため，この現状が一般入試によ る入学者と, 推薦・ $\mathrm{AO}$ 入試による入学者の学力に
おける「基礎的な知識及び技能」の差として現れ ていると考えられる。したがって，「基礎的な知識 及び技能」だけではなく「これらを活用して課題 を解決するために必要な思考力・判断力・表現力 等の能力」や「主体的に学習に取り組む態度」を 入学試験で確認したいのならば，それに沿った内 容へと転換する必要がある。

こうした現状を踏まえ，中教審は「既存の『大 学入試』と『公平性』に関する意識を改革し，年 齢，性別，国籍，文化，障害の有無，地域の違い， 家庭環境等の多様な背景を持つ一人ひとりが，高 等学校までに積み上げてきた多様な力を，多様な 方法で『公正』に評価し選抜するという意識に立 たなければならない.」(p.8)と，「公平性」から「公 正」への転換を高大接続改革の方針として示して いる。

以上の方針のもと，高大接続改革の具体的な方 向性としては, 次の 2 つが挙げられている(p.11-20).

(1)各大学のアドミッション・ポリシーに基づく, 大学入学希望者の多様性を踏まえた「公正」な選 抜の観点に立った大学入学者選抜の確立

(2)高等学校教育の質の確保・向上

(1)は，知識を再生する力ではなく，大学の入口 段階で求められる力を多面的・総合的に評価する という取組である。その内容はさらに，1)各大学 の個別選抜改革，2)入学希望者に求められる学力 を評価する新テストの導入として具体化されてい る.

(2)では，全ての生徒が共通に身につけるべき資 質・能力の育成という「共通性の確保」と，多様 な学習ニーズへのきめ細やかな対応という「多様 化への対応」の両者のバランスを取りながら進め ていくことが目指されている．具体的には，1)高 等学校段階の基礎学力を評価する新テストの導入, 2)高等学校の教育内容や学習・指導方法，評価方 法等の見直し，3)大学教育の質的転換の断行，4) 新テストの一体的な実施が挙げられている.

以上のように，2014 年，中教審は高大接続改革 の方針を明確に定めた。その方向性は，学生の能 力の評価基準を「知識の再生」から「確かな学力」 へ転換させようとする試みであると言うことがで きる．個別選抜改革や，新テストの実施は，これ まで評価されなかった学生の能力を測ることが目 的となっている。そして，高等学校・大学が同心゙ 方向を向いて共に改革を行うことで，両者の接続 
が容易になるというのが同改革の持つ意義である. 一方近年では，大学で求められる能力・姿勢を 学生が持っていないことへの対応策として，初年 次教育にも注目が集まっている，次章では，初年 次教育の現状について述べる.

\section{3. 初年次教育の現状}

\section{1. 定義}

近年，日本において初年次教育は急速に広がり を見せている. 初年次教育とは，1970年代後半か らアメリカの高等教育機関において導入され, 2000年代に日本にも広まってきた教育プログラム である。

中教審は2001年に初年次教育の定義を行ってい る. 同答申は,「人生の新たな段階，未知の世界へ の「移行」を支援する取組として, 初年次教育一 の注目も高まっている」としながら，「高等学校 や他大学からの円滑な移行を図り, 学習及び人格 的な成長に向け，大学での学問的・社会的な諸経 験を成功させるべく，主に新入生を対象に総合的 につくられた教育プログラム」あるいは「初年次 学生が大学生になることを支援するプログラム」 と初年次教育を定義している ${ }^{[4]}$.「初年次教育」 概念に関する基本的な定義を中教審答申に求める ことについて, 谷川(2013)は同答申で示された提案 は, 今後現場の指針となる(すでになっている)可能 性が高い」と述べている[5].

本稿では中教審の定義に従い, 初年次教育を「高 等学校や他大学からの円滑な移行を図り，学習及 び人格的な成長に向け，大学での学問的・社会的 な諸経験を成功させるべく，主に新入生を対象に 総合的につくられた教育プログラム」と定義する. 次節では，初年次教育の近年の動向について述心゙ る.

\section{2. 初年次教育の近年の動向}

2014年11月14日に文部科学省が発表した「大学 における教育内容等の改革状況について」による と，学部段階において初年次教育を導入している 大学は695大学(94\%)あり, 前年の651大学(88\%)か ら増加している[5]. その取り組み内容は主に,「レ ポート論文の書き方等の文章作法」「プレゼンテ ーション等の口頭発表の技法」「学問や大学教育 全般に対する動機づけ」「将来の職業生活や進路 選択に対する動機づけ」となっており，いずれも
初年次教育を行っている大学の約8割が実施して いる. 文章作法や口頭発表の技法, 学問や大学教 育全般に対する動機づけのためのプログラムや, 将来の職業生活や進路選択に対する動機づけ・方 向づけのためのプログラムを開設する大学が多い.

こうした初年次教育が多くの大学で導入される ようになった背景として，山田(2012)は次の3点を 挙げている[6].

(1)学生の変化

(2)政策的側面の変化

(3)社会から求められる教育効果の提示といった 内在的及び外在的な圧力の存在

2点目の「政策的側面の変化」とは，大学をより 教育を重視する場へと変革させるような政策の存 在のことを意味する。こうした政策面での変化に 関して，山田(2012:p.32)は「2008年の中央教育審議 会が公表した『学士課程答申』において, 初年次 教育が初年次における教育の配慮として，高等学 校との緊密な連携の推進とともに，学部・学科等 の縦割りの壁を越えて，充実したプログラムを体 系的に提供していくことが求められたことが大き い」と述べている.

このように広がりを見せる初年次教育であるが， その概念がアメリカから導入された 2000 年代初頭 では，日本において理論も実践も不足していると いう状況にあった。こうした初年次教育の基礎研 究不足を背景として，2008年に初年次教育学会が 発足した。同学会は初年次教育について,「日本で も初年次教育は急速な拡がりを見せ始め, 研究者 による研究の成果や担当教職員による効果的なプ ログラムの構築が増加して」いるとした上で,「し かし，まだまだ日本での実践や研究実績の蓄積と それらの共有は十分とはいえず，実践的な教育内 容や効果的な教育方法の開発や改善に加え，初年 次教育の教育効果の測定や理論的な説明をはかり， 初年次教育のもつ重要性を日本の高等教育化に定 着させていく必要が高まっています」と述べてい る.

初年次教育は, 学生の大学への適応や, 学習へ の動機づけを強化するものとして期待されている. 次節では，近年行われている実際の初年次教育の 内容とその効果について述べる.

3.3. 実際に行われている取組み内容とその効 果 
大学入試を終えた学生は, しばしば学習への動 機づけを維持することが難しくなる．そのため, 入学後も学生の学習意欲を損なわないようにする ために，大学側は種々の工夫をこらしている．本 節では大学が実際に行っている初年次教育の内容 とその効果について, 金沢工業大学と三重大学の 例を引きながら説明する.

金沢工業大学では，1 年次を大学生活の基盤を 作り, 将来を定める期間とみなし, 初年次授業科 目として「修学基礎 $\mathrm{A} 」$, 「修学基礎 $\mathrm{B}$ 」を設けて いる ${ }^{[7]}$ 。「修学基礎 $\mathrm{A} 」 は ， 1$ 年次前学期の必修科 目であり，学習や生活に意欲的に取り組む動機づ けを行うと同時に文章作成やグループ討議・発表 方法などコミュニケーション力をつける基本を学 ぶものである。「修学基礎 B」は， 1 年次後学期の 必修科目であり, キャリアデザインについて学び, 将来の目標を考えるきっかけを持たせることを狙 いとしている.

1 年次前学期では, グループ学習のメリットや 学習する習慣を身につけることなどについて授業 で繰り返し説明し，学習時間を増やして基礎学力 を身につけるように働きかけた。その結果, 勉強 する意欲がないという学生は 2011 年度と 2012 年 度入学学生とも 2 年連続して大きく減少した。ま た, 課題の提出遅れをする学生の数も減った. こ の結果について, 山田(2013:p.32)は「学生の立場に 立って学生と接すれば学習意欲を失わずに大学生 活を過ごす多くの学生を育てることができた」と， 初年次教育と学生の学習への動機づけとの因果関 係を示唆している。

山田(2013:p.33)は, 1 年次後学期では, キャリア デザインに関する様々な取組みを行い, 学生に将 来の目標を考えるきっかけを持たせようと試みた. その結果, 約 9 割の学生が自分の将来について考 えるようになった。ここでは，「自分の専門領域に 関連する企業を調査し，その企業の業務内容の分 析を行い，その企業で働くためにはどのような知 識と能力を身につけるべきか」という小論文が課 されたものの, 課題提出の 3 週間前には約 $81 \%$ の 学生が調べるべき企業がわからず手を付けられて いなかった. しかし, 日本の産業分類や, 最近 4 年間に先輩の就職した企業名の産業別分類などの 解説を行った結果, 約 98\%の学生が「小論文のテ 一マとして取り上げる企業が決まりそうだ」と答 えることとなった。
以上のように, 金沢工業大学では, 1 年次前学 期にはグループ学習や学習する習慣作りなどの対 策を，後学期には様々なキャリアデザイン教育を 行った。 そしてその結果，学生に将来の目標を定 めるきっかけを与えることができている.

この金沢工業大学の取組みは, 大学側が学生に 対して直接働きかけることより，学習への動機づ けを与えることに成功した事例と見ることができ る. その一方で, 三重大学は協働学習によって学 生の社会的動機づけが強化されることを示してい る. 以下に，三重大学の試みについて述べる.

三重大学では, 初年次に行われている協働学習 における社会的動機づけの変化についての調查を 行った ${ }^{[8]}$.ここでは協㗢学習は, 学習者同士が相 互に協力しながら共通の目標に向かう学習と定義 されている. 協働学習は学習者の学習意欲を高め るものとして期待されているが，「他者からの刺激 による動機づけ」やグループの友人に嫌われたく ないという「被嫌悪回避動機」が学習への動機づ けの要因となっていることが明らかになっている. 同調査の結果では，学習を進めることにより，「他 者からの刺激による動機づけ」が強まり, そのこ とが大学への適応感を強めていることがわかった. また一方で，学生は他のメンバーから嫌われたく ないという「メンバーからの被嫌悪回避動機」を 持つが，この動機は大学への適応感を阻害する恐 れがあることが示された.

これらの結果を踏まえ, 中西・他(2013)「適応感 を促すことを視野に入れた協同学習の支援を考え るならば，他者の頑張っている姿に触発されるよ うにし，他者から新たな知識を得ようとすること を促しながら，他者から嫌われないようにという 意識を低減させられるような支援を行うことで， 対人関係・学業の両方の適応感を促すことにつな げられるかもしれない。 また，他者を助け，グル ープ全体で評価されようとすることを促すことで, 学業的な適応感を高めることにつながるかもしれ ない.」と，結論づけている.

この事例からは，学生同士にグループ学習をさ せることによって，学習への動機づけを強められ る可能性が示唆されている. 学生の学習状況の確 認および指導を行う役割は, 通常教員に課せられ ている。しかし，一般に学生の人数に対して教員 の数は少ない. そのため, 教員も講義やその準備 があるため十分な指導を行うことが難しいと考え 
られる。 そうした中で，グループ学習を積極的に 取り入れることで, 学習への動機づけを効率的に 行うことが可能であると言える.

ここまで，初年次教育時に学生一動機づけを与 えるための実際の試みを見てきた．金沢工業大学 では大学が学生個人に直接働きかけるという方法 で，また三重大学では協働学習を通じて動機づけ を強化するという方法でそれぞれ成果を挙げてい る. しかし, 教員による個別面談を実施する場合, 教員の負担が増大寸ることが想定される.

\section{4. 今後の課題}

本論では，大学で実施されている初年次教育の 現状について述べた. 大学生に求められる能力・ 姿勢を学生が入学時に持っていないという問題に ついて，金沢工業大学・三重大学ではそれぞれグ ループ学習の実施によって学生への動機付けを行 っていた.

高大接続改革において中教審は，高等学校及び 大学における学生の評価基準を変更するという方 向性を示している。 それは, 個別選抜改革や新テ ストの導入により,「知識を再生する力」から「確 かな学力」を評価するというものである.

一方で, 初年次教育では, 大学入学直後に学生 をフォローするようなカリキュラムを導入するこ とで，学生の学習への動機付けを強化するという 試みがなされている。初年次教育を行う多くの大 学では, 文章作法や口頭発表の技法, 学問や大学 教育全般に対する動機づけのためのプログラムや, 将来の職業生活や進路選択に対する動機づけ・方 向づけのためのプログラムを用意している ${ }^{[9]}$.

この初年次教育の推進は, 中教審が重要性を指 摘している「確かな学力」の形成に寄与寸るもの であると評価できる，現在の高校教育では，知識 伝達型の授業に留まり, また大学入学試験では知 識を問う問題が中心となっている。そのため，知 識の定着が重視され, 大学における研究の基礎と なる文章作法の習得や学問自体への動機づけが, 大学入学時点では十分になされていないと考えら れる。そのため, 初年次教育には, 高校教育にお いて不足している点に対応し,「確かな学力」を身 につけさせることも期待されている.

こうした展望を見せている高大接続改革と初年 次教育であるが，両者には課題がある.

まず，高大接続改革については，現在発生して
いる推薦入試・ $\mathrm{AO}$ 入試入学者の学力不足と同様の 問題が起きる可能性がある. 高大接続改革の中で 示されている個別選抜改革の内容について, 中教 審は「大学入学希望者学力評価テス卜 (仮称)』 の成績に加え, 小論文, 面接, 集団討論, プレゼ ンテーション, 調查書, 活動報告書, 大学入学希 望理由書や学修計画書, 資格・検定試験などの成績, 各種大会等での活動や顕彰の記録，その他受検者 のこれまでの努力を証明する資料などを活用する ことが考えられる.」[10]と述べている。「大学入学 希望者学力評価テスト (仮称)」という学力を測る 試験の導入が示唆されているものの，他の項目は 現在の推薦入試・AO 入試で用いられている評価項 目とほぼ同様である。学力テスト以外を重んじる という評価方法は，大学において必要となる基礎 学力を得る動機づけを学生から奪う恐れがある. そのため, 新たな評価項目を導入しながらも, 学 生の基礎学力を担保するような選抜制度の検討が 課題となる.

次に，初年次教育においては，大学側の膨大な 人的コストが問題となる. 初年次教育で行われる 学生への学習に対する動機づけ強化の中で, 効果 的とされるのはグループ学習や個別面談といった 教員からのフォローが比較的大きい取り組みであ る.しかし，大学の規模は高等学校に比心遥かに 大きいため, 生徒の個別指導に十分な時間を割け ない教員がいることも想定される，そのため，初 年次教育を推し進める場合, オンライン添削や大 学院生によるチューターの活用など, 人的コスト をいかに抑えるかの工夫が重要となると考えられ る.

以上のように，高大接続改革と初年次教育は, その効果が期待される一方で課題も抱えている. 特に高大接続改革に関しては蓄積が不足している 段階であるため, 実際に導入する中で課題の解決 策を模索することが求められている.

\section{引用 · 参考文献}

[1]中央教育審議会：AO 入試等の実施状況につい て, 高大特別部会（第 4 回）配付資料, 2012, p.1-14.

[2]文部科学省：教育再生実行会議第四次提言参考 資料(その 3), 2013, p.23.

http://www.mext.go.jp/b_menu/shingi/chukyo/chuky o0/gijiroku/attach/_icsFiles/afieldfile/2013/12/02/1 342003_3.pdf 
(2016年 3 月 8 日参照)

[3] 日本私立学校振興・共済事業団 : 大学経営強化 の事例集大学経営を成功に導くために, 2007, pp.34-35.

http://www.shigaku.go.jp/jireishu_zenbun.pdf (2016 年 3 月 8 日参照)

[4]中央教育審議会 : 学士過程教育の構築に向けて (審議のまとめ), 2013, p.35.

[5]谷川裕稔：リメディアル教育と初年次教育の概 念枠組みに関寸る研究(中教審答申による定義 の限界とその対案について), リメディアル教育 研究, 第 8 巻第 1 号, 2013, p.57.

http://www.mext.go.jp/a_menu/koutou/daigaku/040 52801/_icsFiles/afieldfile/2015/10/21/1361916_1.p df

(2016 年 3 月 8 日参照)

[6]山田礼子 : 大学の機能分化と初年次教育 : 新入 生像をてがかりに(特集「大学」の機能分化と大 卒労働市場との接続), 日本労働研究雑誌, 2012, 54 巻 12 号, pp.31-43
[7]山田裕憲 : 学習の動機つけと将来目標を考えさ せる初年次教育：学習の習慣作りとリアルな産 業教育の効果, 工学教育研究講演会講演論文集, 2013, 61 巻, pp.32-33

[8]中西良文，中島誠，下村智子，守山紗弥加，長濱 文与, 大道一弘, 益川優子 : 大学初年次教育科目 における社会的動機づけに関する検討，三重大 学教育学部研究紀要, 2015, 66 巻, pp.261-264

[9]山田礼子 : 大学の機能分化と初年次教育 : 新入 生像をてがかりに(特集「大学」の機能分化と大 卒労働市場との接続), 日本労働研究䧱誌, 2012, 54 巻 12 号, pp.31-32

[10]文部科学省 : 各大学における個別選抜を「多面 的・総合的な評価」に改善するための改革に関 する主な論点(案), 2015, p.4.

http://www.mext.go.jp/b_menu/shingi/chousa/shoug ai/033/shiryo/_icsFiles/afieldfile/2015/04/30/13575 12_10.pdf

(2016 年 3 月 17 日参照)

\section{Abstract}

In this paper, first, I describe about the current situation of reformation of articulation between high school and universities and Japanese Association of First-Year Experience. Then, I discuss about the future issues. In articulation between high school and universities, a direction is indicated, which is to change the evaluation standard of students at high schools and universities. On the other hand, in Japanese First-Year Experience, they attempt to fill the gap of students between the ability, which universities require, and the one of students at the time of enrolment. There are challenges in both cases. The former case may take away motivation from students to obtain basic academic skills required at universities. The latter case, huge human cost will be the problem at universities.

（受付日：2016 年 4 月 16 日，受理日：2016 年 5 月 9 日）

川合＼cjkstart宏之（かわい ひろゆき）

現職：流通科学大学商学部講師

立命館大学経営学部経営学科卒業.

専門はキャリア教育，職業教育，高等学校教育，高大接続.

現在は「商業高校におけるキャリア教育・職業教育」,「大学初年次におけるキャリア教育」, 「高大接続 とキャリア教育」をテーマとして，特に商業教育，商業高校に焦点をあてた研究を行っている. 